\title{
ON WIRTINGER'S INEQUALITY AND ITS ELEMENTARY PROOF
}

\author{
Sin-EI TAKAHASI, TAKESHI MiURA AND TAKAHIRO HAYATA
}

Abstract. By an elementary method, we exactly determine the best possible constant and its attaining function which satisfy $\|f\|_{q} \leqslant C_{q}\left\|f^{\prime}\right\|_{q}(1<q<\infty)$ for certain class of continuously differentiable functions on the unit interval $[0,1]$.

Mathematics subject classification (2000): 26D15, 60E15, 47B15.

Key words and phrases: Wirtinger's inequality.

\section{REFERENCES}

[1] J. BRINK, Inequalities involving $f_{p}$ and $f_{q}^{(n)}$ for $f$ with $n$ zeros, Pacific J. Math., 42, (1972), 289-311.

[2] G. H. HARdY, J. E. LitTLEwOOD AND G. PóLYA, Inequalities, Cambridge, at the University Press, 1952, $2 \mathrm{~d}$ ed.

[3] S.-E. TAKAHASI, T. MiURA, A note on Wirtinger-Beesack's integral inequalities, Math. Inequal. Appl., 6, (2) (2003), 277-282.

[4] M. Tsukada, T. Miura, S. Wada, Y. Takahashi and S.-E. Takahasi, On Wirtinger-Beesack type integral inequalities, Nonlinear analysis and convex analysis, Yokohama Publ., Yokohama, 2004, pp. 541-549. 